\title{
Inter-household and intra-household patterns of fish and meat consumption in fishing communities in two states in Nigeria
}

\author{
Ahmed Gomna ${ }^{1}$ and Krishen Rana ${ }^{2 *}$ \\ ${ }^{1}$ Federal College of Education, PMB 39, Kontagora, Niger State, Nigeria \\ ${ }^{2}$ Institute of Aquaculture, University of Stirling, FK9 4LA, Scotland, UK and Division of Aquaculture, Department of Genetics, \\ Stellenbosch University, South Africa
}

\begin{abstract}
Fish is generally regarded as a primary source of protein for many poor African fishing communities. The present study compared the relative importance of fish as a high-quality dietary protein source with meat in fishing communities in two states in Nigeria. Fifty fishing households in which active fishing was the primary activity and fifty non-fishing households (agriculture being stated as primary activity) in traditional fishing communities were randomly selected in the coastal state of Lagos and the inland state of Niger. A simple weighing balance was designed and given to each household to measure fish or meat entering the household for consumption. A comparison of consumption using this method against the $24 \mathrm{~h}$ recall method revealed that the recall method accounted for only one third of actual fish consumed. Overall, the price of fish was higher and consumption lower in Lagos compared with Niger State. At the household level in both states, the consumption of fish in fishing households was twice that of non-fishing households, whereas meat consumption was similar. A total of thirty-nine different fish species were consumed, with Tilapia contributing $24 \%$ by weight of the fish consumed. In both states, beef was the most frequently consumed meat, followed by goat meat. The study revealed a high preference for fresh fish. The highest fish consumption occurred in March, corresponding to the period of lowest meat consumption. On a unit weight basis, heads of households consumed $59 \%$ more fish than their wives or children.
\end{abstract}

Nigeria: Fish and meat consumption: Intra-household fish consumption patterns

Meat and fish form an integral part of the diet of Nigerian people and are considered to be essential protein foods, also serving as a focal point for the family meal (Elliot \& Ezenwa, 1988). The relative contribution of each these protein sources, however, may vary depending on the livelihood activities of the family, their income and fish availability. In rural and fishing communities in Nigeria, fish is known to play a significant role in the diet, providing up to $75 \%$ of the total animal protein intake (Department for International Development-Food and Agriculture Organization, 2002). In many developing countries, the dependency on fish remains high as substitutes in the form of other animal foods are inaccessible to the poor (Kent, 1987). The actual quantity of animal foods consumed is, however, poorly documented.

The range of fish species utilised by fishing and rural communities is also largely unknown, although it is commonly accepted that Tilapia species that are sourced from openaccess bodies of water make a notable contribution to household consumption. The nutritional value of fish and meat, in terms of both protein and micronutrients, in child development is well documented (Bender, 1992; Mori et al. 1999; Addis, 2004). The availability of and access to fish within a household can therefore be an important determinant of its members' well-being. At the household level, the consumption patterns may depend on the availability of hard currency, the primary activity of the household and the social structures and customs. Fishing communities are frequently identified as being among the poorest of the poor (Jazairy et al. 1992) and are often characterised by overcrowded living conditions and inadequate services, low levels of education and a lack of skills and assets (particularly land) that would permit a diversification of their livelihoods (Townsley, 1998).

The aim of the present study was therefore to test the premise that fish are an important source of protein in fishing communities when compared with meat in two states in Nigeria by examining the diversity of fish species and meat consumed, and investigating the comparative importance of intra-household consumption patterns of fish and meat.

\section{Method}

Selection of states and households within fishing communities

Two states with different eco-zones and cultural backgrounds were identified for the study: Niger, an inland state with a predominately Muslim population, and Lagos, a coastal state with a predominantly Christian population (Fig. 1). In each state, a stratified scheme for randomly selected households was used. Households were grouped by the primary occupation of the head of the household. Those heads of households in fishing communities stating fishing as their primary occupation were classified as fishing households. Households in which other 


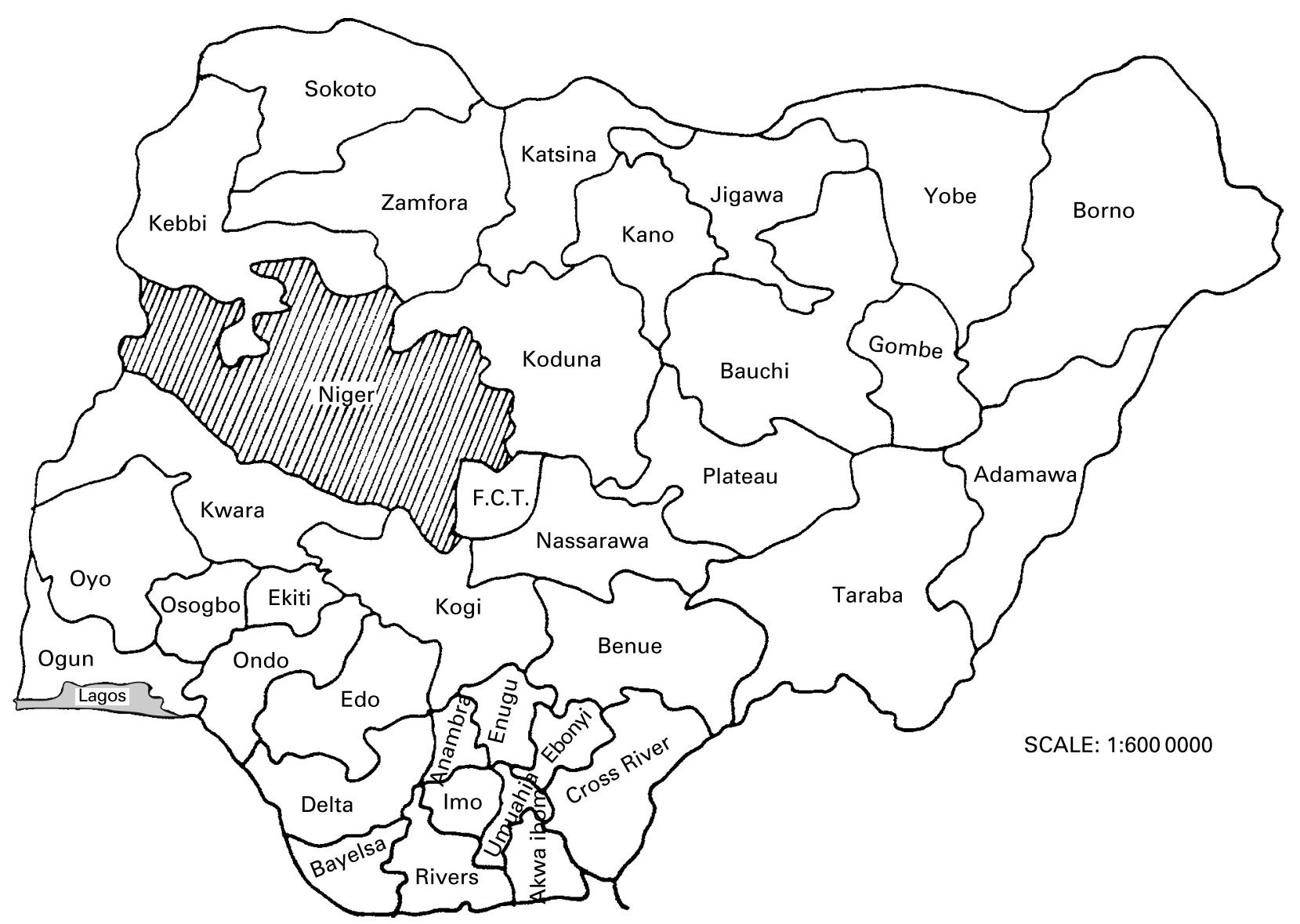

Fig. 1. Map of Nigeria showing the study sites: Niger (河) and Lagos ( $\square$ ) states.

activities were given as their main occupation but where fishing could also be an additional activity were classed as non-fishing.

A total of fifty fishing and fifty non-fishing households in fishing communities in Niger and Lagos states were randomly selected for the study. These households were randomly selected from five fishing villages in each of the two states. In each village, five fishing and five non-fishing households were randomly selected for the study. The sampling strategy is outlined in Fig. 2. For each household, the ages of household members and the income of the head of the household were recorded.

\section{Recording of daily fish and meat intake by households}

To obtain quantifiable information on consumption, a simple field weighing balance was designed utilising dry sand and stones for weights (Fig. 3(A)). Each household was given the field balance to measure the weight of fish or meat entering the household for consumption. The fish to be weighed was placed on one side of the scale and then balanced with locally sourced stones and dry sand (Fig. 3(A)). After balancing items with the stones and the dry sand, the sand and stones were transferred and stored in a labelled polythene bag. If two or more species of fish were eaten, the species were weighed separately. The stones and sand that balanced the weight of the different species of fish, together with species names, were kept in different labelled polythene bags. The polythene bags were then tied and stored within a larger polythene bag. The consumption of meat was estimated in a similar manner. The stones and dry sand were measured the following day or later by an extension agent using a calibrated scale (Fig. 3(A)). The weight of the stones and sand indicated the weight of the fish or meat eaten by the household and the fish species recorded. Fish or meat intake was recorded daily for 7 months (January-July 2003).

\section{Intra-household fish consumption and distribution}

A $24 \mathrm{~h}$ recall method was used to obtain the amount of fish eaten by individual members within each household. Fish samples were shown to the members of the household, who were asked to pick the fish similar in size to the one they had eaten the previous day. This fish was then weighed and the result recorded to represent the amount that person had consumed. This value was also used to verify data collected the previous day. In some cases, the wife who cooked and distributed the fish was asked to pick the fish similar in size to the one she had given to the head of household, the women and the children. The fish was then weighed and recorded as that eaten by them. They were also asked to recall the parts of fish eaten and the parts thrown away. Information on the form of the fish used for cooking (fresh, smoked, dried) and source of the fish (river, lagoon, sea, market) was also obtained using the $24 \mathrm{~h}$ recall method.

\section{Statistical analyses}

The relationship between fish consumption and income was analysed using Pearson correlation. The general linear model was 


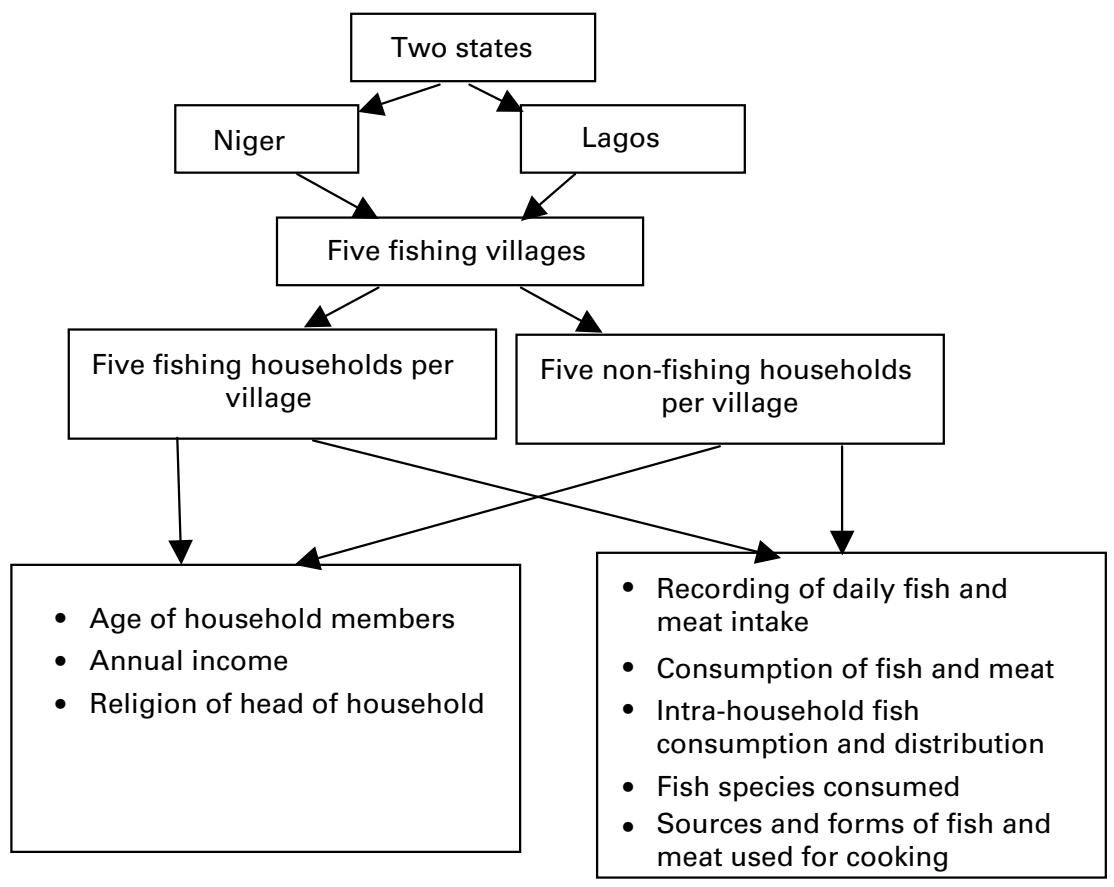

Fig. 2. Sampling strategy used for selecting households.

used to analyse fish consumption to establish significant $(P<0.05)$ differences in monthly fish consumption in fishing and non-fishing households in fishing communities in Niger and Lagos states (Minitab software 14.12; State College, PA, USA). The data were not normally distributed and were therefore transformed to obtain the best fit. Square-root transformation gave better results and was therefore used for the analysis.

\section{Results}

The mean family size of all the surveyed households in the fishing villages was 7.0 members, and about $90 \%$ of the children in the households were below the age of 16 .

In fishing households, the main income was derived from fishing, whereas crop farming was the main source of income in non-fishing households. About $98 \%$ of fishing households had crop farming as a secondary occupation, and only $2 \%$ were involved in petty trading. About $76 \%$ of non-fishing households had fishing as a secondary occupation, while others were involved in petty trading and hunting.

\section{Consumption of fish species and meat}

In total, thirty-nine different species groups were consumed in fishing villages. The species consumed in Niger were exclusively freshwater fish, whereas those consumed in Lagos were both fresh and brackish water species. Two local government areas in Lagos had a freshwater lagoon as their main source of fish.

A total of twenty-five and twenty-two fish species groups were consumed in Niger and Lagos states, respectively (Fig. 4). In Niger state, Tilapia species were consumed with highest frequency (19\%), followed by Synodontis (14\%) and Mormyrops species $(11 \%)$. The least consumed species group were snails. Tilapia species were also consumed with

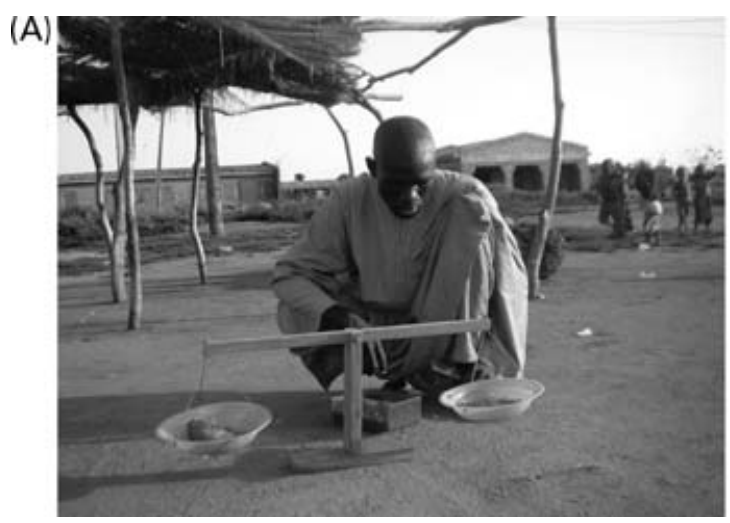

(B)

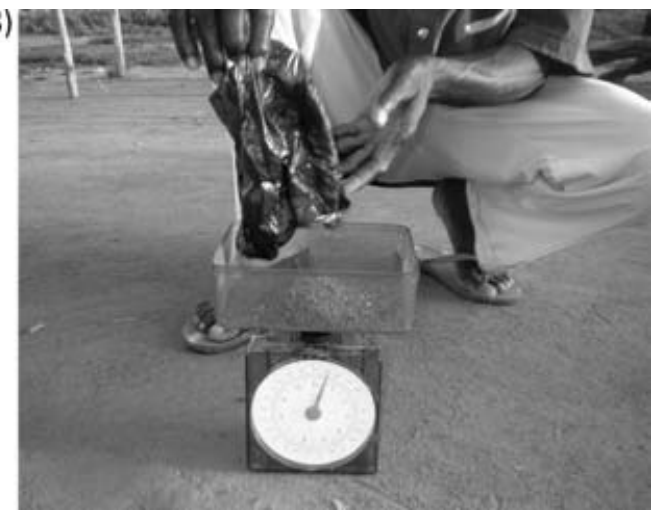

Fig. 3. The design and procedure for measuring fish and meat using a simple balance. (A) A member of the household balancing fish with locally sourced stones (coarse balancing) and dry sand (fine balancing). (B) An extension agent measuring the stones and dry sand with an actual scale at the time of his visit. 
highest frequency (31\%) in Lagos, followed by Caranx $(8 \%)$ and Sphyraena (Barracuda) species (7\%). The least consumed fish species was titus ice fish (Scomber japonicum).

Sixteen types of meat were also consumed by fishing and non-fishing communities in the two states, although three meats were consumed at a notable level. Beef was the most frequently eaten meat $(47 \%)$, followed by goat meat $(20 \%)$ and chicken (14\%). Grass-cutter was the bush meat that was eaten with the highest frequency $(9 \%)$. The least consumed meat was lamb $(<0.5 \%)$.
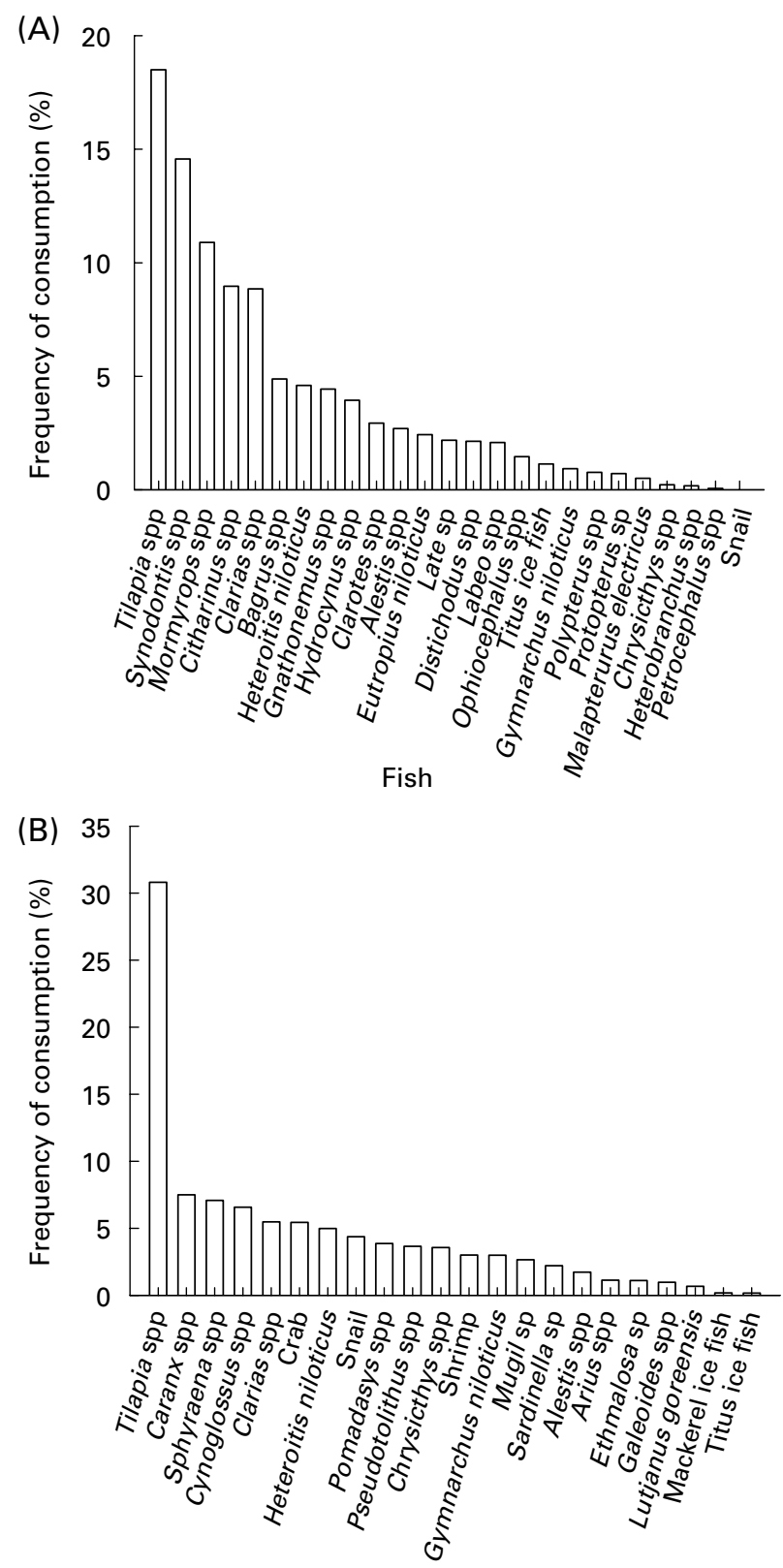

Fish

Fig. 4. Overall consumption frequencies of fish species in fishing communities in (A) Niger and (B) Lagos states. Species consumed in Niger were exclusively freshwater fish, whereas those consumed in Lagos were both fresh and brackish water species. Two local government areas in Lagos had a freshwater lagoon as their main source of fish. Data not shown are too small to appear on the scale.

\section{Household consumption patterns of fish and meat}

All fishing and non-fishing households selected for this study consumed fish throughout the survey period, and feedback from participatory meetings with fishing villages confirmed that fish was consumed throughout the year. The consumption patterns of fish in Niger and Lagos states are given in Fig. 5(A). Fish consumption in Niger was almost twice that in Lagos. The average daily weights of fish consumed per household in Niger and Lagos were $217 \mathrm{~g}(79 \mathrm{~kg} / \mathrm{year})$

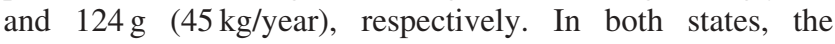
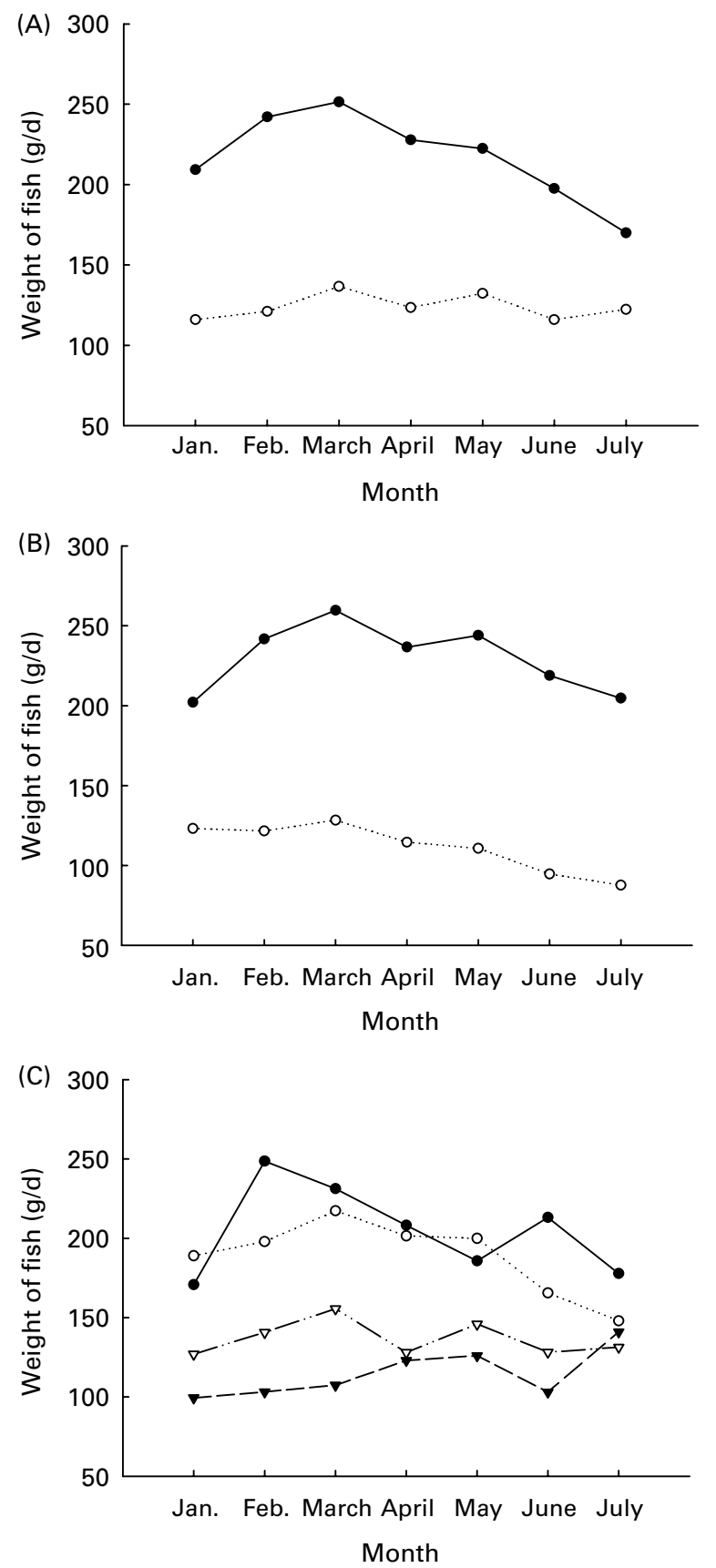

Fig. 5. The temporal fish consumption pattern in fishing communities in $(A)$ Niger $(\bullet)$ and Lagos $(\bigcirc)$ states, $(B)$ fishing $(\bullet)$ and non-fishing $(O)$ households, and $(C)$ mud-thatched $(\bullet)$, mud-zinc $(\bigcirc)$, bamboo huts $(\nabla)$ and plankzinc $(\boldsymbol{\nabla})$ households. 
consumption of fish was significantly higher in fishing than non-fishing households (Fig. 5(B)). Overall, fishing households consumed an average of $230 \mathrm{~g}$ fish/d compared with $111 \mathrm{~g}$ fish/d for non-fishing households, which corresponded to an extrapolated annual household fish consumption of 84 and $41 \mathrm{~kg} /$ year for Niger and Lagos, respectively. This corresponds to an annual consumption of 12 and $5.8 \mathrm{~kg} /$ person, respectively.

In this study, basic house construction was used as an indicator of wealth. The house types in decreasing order of wealth ranking identified in the study area were mud-zinc, plank-zinc, bamboo huts and mud-thatched. The majority of mud-thatched (96\%) and mud-zinc (86\%) households were found in Niger state. Plank-zinc and bamboo huts were only found in Lagos state.

Mud-zinc households had a higher annual income (N295 $259 ; 1$ US $\$=\mathrm{N}$ (Naira) 128 in 2003 during the time of the study)) than plank-zinc (N291 697), bamboo hut (N266 624) and mud-thatched (N246 621) households. The consumption of fish was, however, higher in mud-thatched households ( $205 \mathrm{~g} /$ household per day) than mud-zinc (188 g/household per day), bamboo huts (137 g/household per day) and plankzinc (115 g/household per day) households (Fig. 5(C)). There was no significant relationship between fish consumption and income $(r-0.025, P=0.801)$.

Meat consumption was also higher in Niger than Lagos state (Fig. 6(A)). The average daily weight of meat consumed per household in Niger and Lagos states was 61 and $38 \mathrm{~g}$, respectively. Non-fishing households consumed greater amount of meat $(51 \mathrm{~g} / \mathrm{d})$ than fishing $(48 \mathrm{~g} / \mathrm{d})$ households (Fig. 6B). Mud-zinc and mud-thatched households consumed an average of $57-58 \mathrm{~g}$ meat/d, compared with $36 \mathrm{~g}$ for plank-zinc and $35 \mathrm{~g}$ for bamboo hut households (Fig. 6(C)).

The consumption of fish was higher than that of meat in fishing communities in both states in Nigeria. The average daily weight of fish consumed per household was $171 \mathrm{~g}$ (62 kg/year), compared with $50 \mathrm{~g}$ ( $18 \mathrm{~kg} /$ year) for meat. Fish consumption was highest during March (190 g/household per day), corresponding to the period of lowest meat ( $40 \mathrm{~g} / \mathrm{house}$ hold per day) consumption. Meat consumption was highest in February. The average daily weight of fish consumed per person was $24 \mathrm{~g}$ (9 kg/year), and that of meat $7 \mathrm{~g}$ ( $3 \mathrm{~kg} /$ year).

There were highly significant $(P<0.001)$ differences in overall monthly fish consumption between fishing and nonfishing households in fishing communities in Niger and Lagos states. In both states, the average daily fish consumption in all the months (January-July) in fishing households was significantly $(P<0.001)$ higher than that of non-fishing households. The significant differences are summarised in Fig. 7.

\section{Sources and forms of fish and meat used for cooking}

The rivers were the major source of fish consumed $(61 \%)$ by all the households, followed by lagoons (18\%), markets $(14 \%)$, creeks $(5 \%)$ and the sea $(2 \%)$, whereas local markets were the major source of meat $(93 \%)$. About $5 \%$ of the meats eaten were bush meats. Some households had animals $(2 \%)$ that were occasionally slaughtered and eaten, especially during festivals. Most of the fish and meats consumed during the study were cooked in fresh form. Smoked,
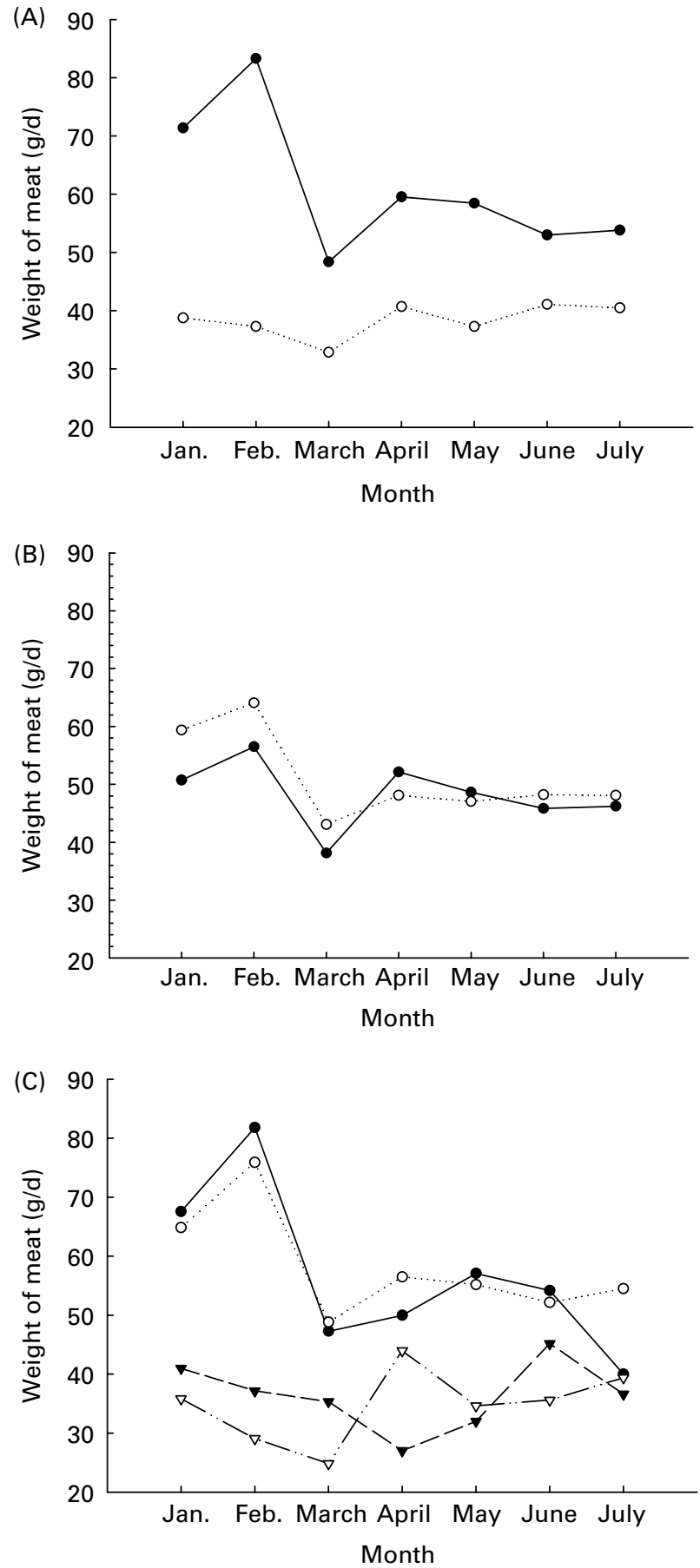

Fig. 6. Temporal consumption patterns of meats in fishing communities in (A) Niger $(\bullet)$ and Lagos $(\bigcirc)$ states, (B) fishing $(\bullet)$ and non-fishing $(\bigcirc)$ households, and $(C)$ mud-thatched $(\bullet)$, mud-zinc $(O)$, bamboo huts $(\nabla)$ and plank-zinc ( $\mathbf{\nabla})$ households.

frozen, dried and roasted fish and meat were only occasionally cooked.

Price of fish species and meat in two states in Nigeria

The price of fresh or smoked fish was significantly higher in Lagos than Niger state. The higher priced fish in Lagos 


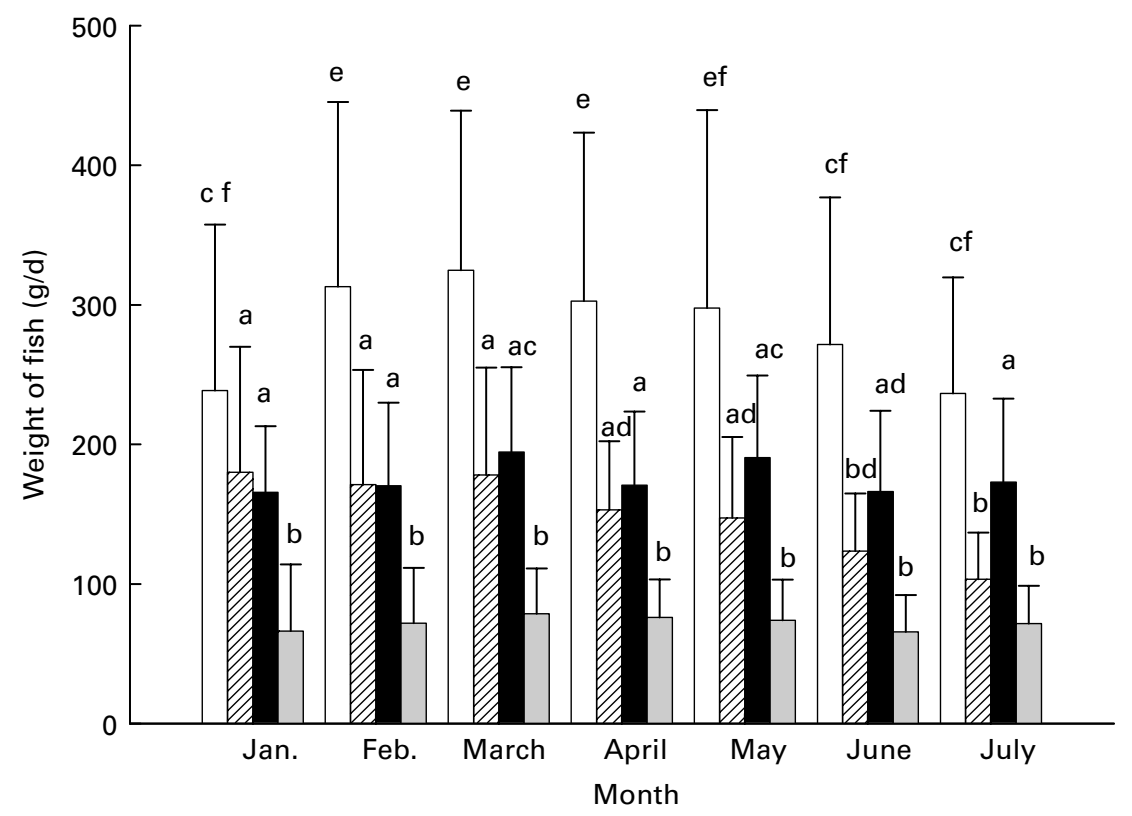

Fig. 7. Average daily weights of fish consumed within each month in fishing and non-fishing households in fishing communities in Niger and Lagos states (mean values with standard deviations indicated by vertical bars). Values with unlike superscript letters were significantly different: $P>0.05$. $\square$, Niger, fishing households; 四, Niger, non-fishing households; $\mathbf{0}$, Logos fishing households; $\square$, Logos, non-fishing household.

were of brackish and marine species. Sphyraena species (barracuda) were the highest-priced fish, fetching three times the price of the cheapest fish, i.e. Tilapia. Other brackish and marine species were twice as expensive as Tilapia. The average price of fresh Gymnarchus niloticus in Niger was $\mathrm{N} 274 / \mathrm{kg}$, compared with $\mathrm{N} 422 / \mathrm{kg}$ for Barracuda in Lagos state, whereas fresh Tilapia, the most commonly eaten fish, fetched N131 and N154/kg in Niger and Lagos state, respectively.

The prices of all fresh meats were also higher in Lagos than Niger state. Chicken was the most expensive meat, selling at an average price of $N 765 / \mathrm{kg}$ in both states, followed by lamb (N570/kg), goat meat (N507/kg) and beef (N462/kg).

\section{Intra-household fish consumption and distribution}

On a unit body weight basis, the heads of households consumed $59 \%$ more fish than their wives or the children. The average weight of fish consumed by the head of the household was $0.27 \mathrm{~kg}$ fish $/ \mathrm{kg}$ body weight per year, compared with $0.17 \mathrm{~kg}$ fish $/ \mathrm{kg}$ body weight per year for the wife and child (Table 1).

On occasions when a single fish was shared within the household, the body of the fish was given to the head of the household on eight out of ten occasions, the tail to the wife on seven out of ten occasions, and the head to the children on eight of ten occasions. Members of the household ate every part of the fish. Chewed bones were discarded only when large fish were eaten.

\section{Discussion}

A simple field balance was designed and used in this study in order to obtain quantifiable information on fish and meat in fishing communities to reduce cost of operation and improve accuracy, thereby providing more meaningful results than the commonly used recall method. In the present study, this approach demonstrated that the recall method accounted for only one third of the actual fish consumed (57v. $171 \mathrm{~g} /$ household per day). Previous studies (Zhai et al. 1996; Core, 2003) also found a significant underreporting of food intake using the $24 \mathrm{~h}$ dietary recall method, highlighting the need for care in interpreting recall data, especially when planning feeding programmes.

\section{Consumption of fish species and meat}

A large number of species (thirty-nine) were consumed by the fishing communities in both states, emphasising the importance of the sustainable management of the aquatic biodiversity in these ecosystems. Tilapia was the most abundantly consumed species in both states, probably reflecting the finding of Ita (1993) that these species comprised the highest relative abundance in local rivers. In the coastal state of Lagos, Tilapia were also sourced from two freshwater lagoons. The high

Table 1. Average weights of fish consumed per body weight by members of households in fishing communities in two states in Nigeria

\begin{tabular}{lccc}
\hline & \multicolumn{3}{c}{ Members of households } \\
\cline { 2 - 4 } & Head of household & Wife & Child \\
\hline $\begin{array}{l}\text { Mean weight of fish consumed } \\
\text { (kg/person per year) }\end{array}$ & 24 & 12 & 5 \\
$\begin{array}{l}\text { Estimated body weight (kg) } \\
\begin{array}{l}\text { Weight of fish consumed } \\
\text { per unit body weight } \\
\text { (kg/body weight per year) }\end{array}\end{array}$ & 90 & 70 & 30 \\
\hline
\end{tabular}


Table 2. Average weights of fish and meat consumed per household per year in fishing communities in Niger and Lagos states*

\begin{tabular}{|c|c|c|c|c|}
\hline \multirow[b]{3}{*}{ State } & \multicolumn{4}{|c|}{ Weight (kg/household per year) } \\
\hline & \multicolumn{2}{|c|}{ Fish } & \multicolumn{2}{|c|}{ Meat } \\
\hline & Fishing households & Non-fishing households & Fishing households & Non-fishing households \\
\hline Niger & 103 & 55 & 23 & 21 \\
\hline Lagos & 64 & 26 & 12 & 16 \\
\hline Average of two states & 84 & 41 & 18 & 19 \\
\hline
\end{tabular}

*Data based on households' fish and meat consumption survey.

consumption of Tilapia may, however, also be due to a preference for this fish (Dreschl et al. 1995) and a low market price, resulting in fishing households consuming these species rather than selling them and non-fishing households being able to afford to purchase them.

Beef was the meat consumed with the highest frequency, which agrees with the findings of Ladele et al. (1996). These authors attributed this to the high availability of chicken. In this study, beef was nearly two-thirds the price of chicken, and therefore its high consumption could also be due to its relatively lower market price.

\section{Household consumption patterns of fish and meat}

Fishing communities in Niger consumed twice as much fish and meat than those in Lagos (Table 2). This higher consumption was probably the consequence of the access that fishermen had to open bodies of water to fish or to construct traditional aquaculture systems, and not having to pay for fish they consumed. The lower consumption rates of fish in Lagos state could be due to fishing households selling more of their fish catch to generate income in Lagos markets where prices are higher, and to nonfishing households buying less due to relatively higher prices.

Households' pattern of consumption of fish varied during the year. In both states and in fishing communities, more fish were consumed between March and May, which coincided with peak fish landings and high earnings (Dreschl et al. 1995). The consumption patterns of fish also appear to be related to the labour time management of the household heads with respect to the rains. The low consumption of fish in June and July coincided with rainy season, when fishermen also work on their farmlands. Low fish consumption during this period may also be attributed to bulk sales of fish to generate income to procure seed and hire labourers. Although January and February are periods of low fish availability, fishermen are actively engaged in fishing during this period as they do not work on rain-fed farms.

The 7 months covered by the survey included the peak and off-peak seasons for fish availability and consumption. It is therefore assumed that annual extrapolated consumption values could be reflective of annual consumption. Nevertheless, such data should be interpreted with caution. The extrapolated annual mean fish intake in the fishing households surveyed was twice that of non-fishing households. In the current study, there was no significant relationship between fish consumption and income. In contrast, Jolly and Clonts (1993) reported that, as income increased, the relative preference for fish declined and that for red meat increased. They noted that the households in lower socio-economic strata spent more of their income on fish than on meat.

Meat consumption also varied during the year, with peak consumption occurring in February, which coincided with the Muslim festival of Idl Kabir, when rams are slaughtered. About $77 \%$ of the heads of households in the study area were Muslim.

The contribution of fish to household animal protein intake in both states was very marked, accounting for up to $77 \%$ of dietary animal protein intake, a trend also supported by Dreschl et al. (1995) and Essuman (1992). This high consumption among subsistence farmers and others with low purchasing power probably occurred because these communities acquired fish at no monetary cost. In the southern regions of Ghana, meat, eggs and chicken are generally considered to be prestigious foods and are consumed mostly on festive occasions or are used to prepare food for important guests (Essuman, 1992).

About $95 \%$ of the fish eaten during the study were cooked in the fresh form, which concurs with the findings of Adeniyi (1987). The consumption of fresh fish is important since processing after harvest, such as sun-drying, reduces its nutritional quality (Colowick \& Kaplan, 1969; Lilabati et al. 1993; Roos, 2001), although Cutting (1962) suggests that processing loss has relatively little effect on overall nutritive value.

In contrast to findings from Bangladesh (Dreschl et al. 1995), the present study suggests that traditional aquaculture systems and capture fisheries were the main source of fish for fishing communities and supports the observations of Jolly and Clonts (1993). Unlike fish, the market was the most important source for the meat consumed by fishing villages, suggesting that most of the animals owned by fishermen and non-fishermen in the fishing communities in Nigeria were reared for capital and income reasons.

\section{Intra-household fish consumption and distribution}

The intra-household consumption of fish was influenced by the social structure within households. In the present study, fish consumption within households on a unit body weight basis was highly skewed towards heads of households, who consumed $59 \%$ more fish than their wives or children. Similar observations were also noted for the intra-household distribution of the traditional fish dish torcarry in Bangladesh by Roos (2001), and for intra-household fish distribution in Ghana by Essuman (1992). In many agrarian households, this form of food distribution probably reflects the greater energy demands of men who engage in manual labour, 
although, given the multitude of daily tasks carried out by women and children, such as weeding and collecting drinking water and fire wood, this premise is questionable.

The reason offered by most of the women interviewed for the skewed intra-household distribution of fish parts for consumption was that their husbands might be embarrassed if given the fish head or tail. According to the women, the children ate mostly the heads of the fish because they were not as busy as their parents so they had time to spend on eating the heads. Nutritionally, this may be particularly important for children as fish heads contain greater concentrations of vitamin A (Kent, 1987; Roos, 2001). Small whole fish tend to contribute far more to dietary balance than do prepared portions of larger fish (Welcomme, 2001). This is particularly so as fish bones are rich in $\mathrm{Ca}$, which could help in body development, especially in children. Increased fish consumption by children may also be beneficial in areas where lactose intolerance is common or milk is expensive or in short supply (Kent, 1987). The author recommended the use of fish as a weaning food since small children are highly vulnerable to malnutrition.

\section{Conclusion}

In the present study, fish was the preferred protein, its average daily household consumption being 3.4 times that of meat, which confirmed its importance in the diet of rural people. Although a large number of aquatic species were consumed, a few species dominated consumption, Tilapia being the most important. Priority should be given to promoting the sustainability of these ecosystems and enhancing the availability of fish in aquatic systems through improved and assured access to bodies of water and an improved productivity of traditional aquaculture farming systems.

\section{References}

Addis PB (2004) Fish oil and your health. http://www.seagrant.umn. edu/fish/oil.html (accessed 23 May 2005).

Adeniyi JP (1987) Fish consumption in Nigeria: implications for fishery development policies. J West Afr Fish 3, 151-161.

Bender A (1992) Meat and Meat Products in Human Nutrition in Developing Countries. Food and Nutrition Paper 53. Rome: Food and Agriculture Organization.

Colowick SP \& Kaplan NO (1969) Methods in Enzymology. New York: Academic Press.

Core J (2003) Study Examines Effectiveness of Dietary Recall Method. United States Department of Agriculture, Agricultural Research Service.
Cutting CL (1962) The influence of drying, salting and smoking on the nutritive value of fish. In Fish in Nutrition, pp. 161-179 [E Heen and R Kreuzer, editors]. London: Fishing News Books.

Department for International Development-Food and Agriculture Organization (2002) Contribution of fisheries research to the improvement of livelihoods in West African fisheries communities: case study of Nigeria. http://www.sflp.org/eng/fr/003/doc/rpniga2. doc (accessed 19 March 2005).

Dreschl S, Alamu SO \& Adu F (1995) Nutritional Habits and Food Consumption Pattern of Fishing Communities Around Lake Kainji, Nigeria. Technical Report Series 2. New Bussa, Nigeria: Nigerian-German (GTZ) Kainji Lake Fisheries Promotion Project.

Elliot AK \& Ezenwa PC (1988) Animal protein requirement for healthy living in Nigeria. Int J Food Sci Nutr 16, 1-5.

Essuman KM (1992) The role of inland fish in food consumption in West Africa: a review. Annex. Artisanal Fish Containers in Ghana: A Case Study. In Post-harvest Fish Technology. CIFA Technical Paper CIFA/T19, pp. 122-240 [F Teutscher, editor]. Rome: Food and Agriculture Organization.

Ita EO (1993) Inland Fishery Resources of Nigeria. CIFA Occasional Paper no. 2. Rome: Food and Agriculture Organization.

Jazairy I, Alamgir M \& Panuccio T (1992) The State of World Rural Poverty: An Inquiry into its Causes and Consequences. London: Intermediate Technology Publications.

Jolly CM \& Clonts HA (1993) Economics of Aquaculture. Binghamton: Haworth Press.

Kent G (1987) Fish, Food and Hunger: The Potential of Fisheries for Alleviating Malnutrition. Colorado, USA: West View Press.

Ladele AA, Joseph K, Omotesho OA \& Ijaiya TO (1996) Sensory quality ratings, consumption pattern and preference for some selected meat types in Nigeria. Int J Food Sci Nutr 47, $141-145$.

Lilabati H, Bijen M \& Vishwanath W (1993) Comparative study on the nutritive values of fresh and smoked catfish, Clarias batrachus Linn. J Freshwat Biol 5, 325-330.

Mori TA, Bao DQ, Burke V, Puddey IB, Watts GF \& Beilin LJ (1999) Dietary fish as a major component of a weight-loss diet: effect on serum lipids, glucose, and insulin metabolism in overweight hypertensive subjects. Am J Clin Nutr 70, 817-825.

Roos N (2001) Fish consumption and aquaculture in rural Bangladesh: nutritional contribution and production potential of culturing small indigenous fish species (SIS) in pond polyculture with commonly cultured carps. PhD Thesis, Royal Veterinary and Agricultural University, Copenhagen, Denmark.

Townsley P (1998) Aquatic resources and sustainable rural livelihoods. In Sustainable Rural Livelihoods. Papers Presented at the Department for International Development's Natural Resources Advisers' Conference, pp. 139-153 [D Carney, editor]. London: Department for International Development.

Welcomme RL (2001) Inland Fisheries: Ecology and Management. Oxford: Fishing News Books.

Zhai F, Guo X, Popkin BA, Ma L, Wang Q, Yu W, Jin S \& Ge K (1996) Evaluation of the 24-hour individual recall method in China. Food Nutr Bull 17(2), 154-161. 